\title{
Development of the digital competence of students through the electronic course
}

\author{
Natalia Ivanovna Svetlova ${ }^{{ }^{*}}$, Lydia Nikolaevna Vasilieva $^{2}$, and Irina Igorevna Ilyina $^{3}$ \\ ${ }^{1}$ Financial University under the Government of the Russian Federation, Department of Mathematics, \\ Moscow, Russia \\ ${ }^{2}$ Chuvash State University named after I.N. Ulyanov, Department of Automation and Control in \\ Technical Systems, Cheboksary, Russia \\ ${ }^{3}$ Bauman Moscow State Technical University, Department of Fundamentals of Mathematics and \\ Informatics (SUNTs-1), Moscow, Russia
}

\begin{abstract}
The article is concerned with the role of an electronic course in higher mathematics in the development of digital competence of students of technical faculties. The principle of organizing the educational process with the help of an electronic course in higher mathematics, focused on the development of students' digital competence, is considered. The experience of testing an electronic notebook in higher mathematics, which is part of an electronic course, is presented. The experience of the implementation of an electronic notebook in higher mathematics in teaching students at all its stages is considered: the examples of problems solved in seminars are given; the design of classroom lessons is described taking into account the specifics of the academic subject "Mathematical Analysis". The structure of the electronic notebook, including test tasks and cases for intermediate certification of students based on the results of the seminar, is given. The effectiveness of the organization of the educational process using an electronic course in higher mathematics to develop the digital competence of students in a technical direction is shown. The work examines the attitude of students to teaching higher mathematics using an electronic course, their self-assessment of involvement in the educational process. Moreover, the educational results of the development of digital competence were demonstrated. A reliable relationship was confirmed between the level of development of digital competence and the positive attitude of students to a new format of teaching mathematics: an interactive electronic course with a component base in the form of an electronic notebook. Based on the results of the experimental work, it can be argued that the students positively assessed the use of the electronic course in teaching, because have constant access to training materials and to information about the individual trajectory of the course. This interactive development is convenient to use when preparing yourself for classes.
\end{abstract}

Keywords: e-course, e-notebook, digital learning, competence

\footnotetext{
* Corresponding author: svetlovani@mail.ru
} 


\section{Introduction}

Currently, the development of information technology, the interaction of educational organizations on the network, e-learning, the use of the Internet, necessitate the use of qualitatively new opportunities in the field of education. The issue of increasing the level of development of digital competence is becoming relevant. According to the state program of the Russian Federation "Development of Education" for 2019-2025, the program "Digital Economy of the Russian Federation" (until 2024), the Federal State Educational Standards of the third generation (FSES $3++$ ), the process of student learning must be built taking into account priority areas of informatization of society, focused on increasing the intensity of the use of digital technologies, electronic resources and products in the educational process.

The digital transformation of production makes rather high demands on the purposeful development of the professional competence of future engineers, the level of which depends on their professional activity [1]. An engineer should be fluent in digital skills associated with regularly solving complex professional problems in a digital environment, be creative as well as be able to work in a team and do critical thinking.

\section{$2 \quad$ Materials and methods}

The study aims to substantiate the development of digital competence of students of technical departments with the help of an electronic course in higher mathematics and checking the effectiveness of its application in experimental work.

The object of the research is the process of modern professional training of students of technical faculties in the context of the digital age.

The subject of the research is the level of development of the digital competence of students of technical faculties, as the basis of professional competence.

The materials for this study were both foreign scientific sources and domestic research. In the process of research, the authors used theoretical, diagnostic, empirical, experimental methods and methods of mathematical statistics.

The study [2] analyzes the international experience in the development and implementation of electronic educational resources and offers a practical description of the organization of e-learning for teachers in undergraduate programs.

The authors in [3] examine the trends in e-learning and analyze its impact from various points of view.

The article [4] proposes an algorithm for automatic recommendation of resources for training, based on a convolutional neural network. Automated learning resource recommendations are an increasingly pressing issue: they allow learners to discover new learning resources that suit their tastes, and enable eLearning to target their learning resources to the right learners.

E-learning recommendation systems play an important role in helping learners find useful and relevant learning materials that meet their learning needs. Personalized intelligent agents and recommendation systems are widely recognized as solutions to overcome information retrieval problems resulting from information overload in learners. An overview of ontology-based recommender systems for e-learning is given in the work [5].

In the Federal study [6], conducted in 2013, digital competence is understood as "based on the continuous mastery of competencies (knowledge, skills, motivation, responsibility), the ability of an individual to confidently, effectively, critically and safely select and use 
infocommunication technologies in different spheres of life (information environment, communications, consumption, technosphere), as well as his readiness for such activities".

Yachin and Fernandez believe that the concept of "digital competence" includes "confident and critical use of computers, mobile phones, tablets, and interactive whiteboards by students. This competence is based on logical thinking, a high level of mastery of information management and highly developed mastery of digital technology" [7].

Prikhodko considers digital competence as "mastery of methods of searching, structuring, systematizing and critical assessment of information using digital technologies and the global Internet for solving practical, educational and professional problems" [8].

In [9], digital competence is defined as "the readiness and ability to effectively and systematically use infocommunication technologies in different spheres of life based on the possession of information competencies as a system of knowledge".

However, in these works, the definition of the term digital competence of students of technical specialties is not considered.

The research of various aspects of e-learning is the subject of the works of Russian researchers: Vlasova [10], Zhozhikov, Tretyakova, Noskov, and others. Foreign authors such as Akaslan, Allen, Laanpere, Richardson, Seaman, Sheninger, Pratt, Whitby, Corbett, Skoulikari, et al. Scientists pay special attention to the platform on which the training takes place, and the form of organization of the educational process [11-13], the interaction of students with the teacher and ways of solving them.

However, to date, the problem of developing the digital competence of students of technical universities when teaching using an electronic course has not been sufficiently developed.

The analysis of the research showed the need to develop an electronic didactic tool (an electronic course in higher mathematics, including an electronic notebook) to increase the level of development of digital competence of students of technical specialties.

The digital competence of students of engineering specialties is considered by the authors as a set of general professional (GPC-8, GPC-7) and professional competencies (PC-10, PC-12), separated from the federal state standard of higher education for a specialist in the specialty 11.05.01 "Radio electronic systems and complexes" [14].

\section{$3 \quad$ Results}

One of the ways to solve the problem of developing the digital competence of students of technical specialties is to create conditions for the implementation of effective educational activities in higher education institutions [15].

The widespread use of digital technologies in interactive learning makes it possible to switch to an electronic course that promotes the integration of theory and practice through the visualization of the material [16]. Such developments help to develop students' critical thinking, form skills, identify and solve digitalization problems, and develop students' personal professional qualities [17].

An important component of the electronic course is an electronic workbook for the course of higher mathematics. This development allows not only to present and demonstrate the material, but also to interest and awaken the student's motivational mood, to show the necessity and importance of mastering the studied material for their further professional activities.

The structure of the electronic notebook is shown in Fig. 1. 


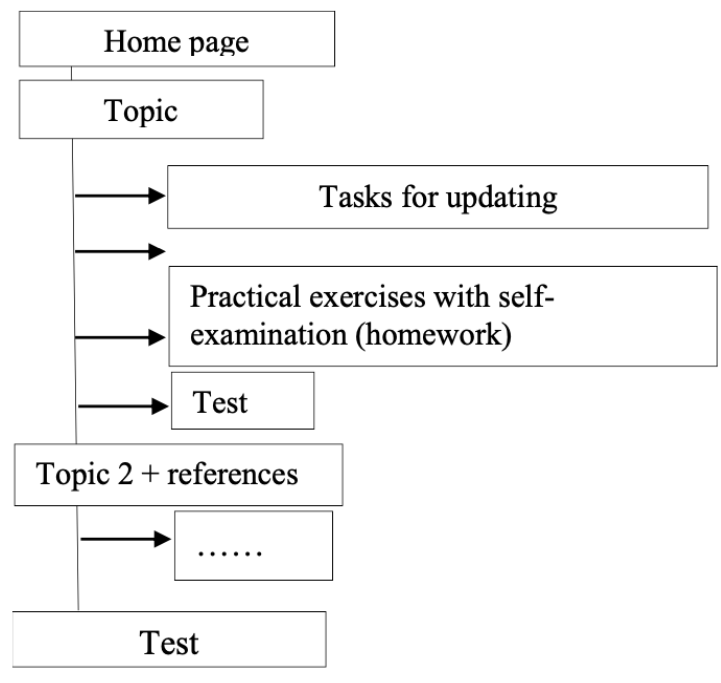

Fig. 1. The structure of the workbook.

The tool for diagnosing the level of digital competence in the study is the result of using an electronic notebook when teaching students mathematical disciplines in the form of an examination assessment, as well as the attitude of students to teaching mathematics using an electronic notebook, their self-assessment of involvement in the educational process [18].

To assess the level of development of digital competence, the following levels were identified: high, advanced, basic.

The high level of development of digital competence of the respondents includes: knowledge of modern principles of working with information (GPC 7), the ability to analyze it and use it to solve problems related to professional activities (GPC 8).

The indicators of the advanced level include: the ability to solve data processing problems using modern information technologies (GPC 7) by means of automation, as well as to have an idea of the digital needs in professional activities (GPC 8).

The basic level assumes: the ability to search and present up-to-date information about the state of the subject area (GPC 7), master the skills of using information and communication tools (GPC 8).

To analyze the level of development of digital competence in the discipline "Mathematical Analysis", the Pearson's criterion of agreement (chi-square) is used. Students of the experimental and control subgroups were divided into three levels in accordance with the level of training (Table 1).

Table 1. Levels of development of digital competence of students in the experimental and control groups.

\begin{tabular}{|c|c|c|c|}
\hline \multirow{2}{*}{ Sample } & \multicolumn{3}{|c|}{ Levels, \% } \\
\cline { 2 - 4 } & Basic & Advanced & High \\
\hline TG & 34 & 51 & 15 \\
\hline RG & 55 & 36 & 9 \\
\hline
\end{tabular}

According to calculations, the value of the $\chi^{2}$ criterion is 9.041 , which is greater than the critical value of $\chi^{2}$ at a significance level of 5.991. In accordance with the decision-making rule, the data obtained allowed us to state that, at the level of significance 
$\alpha=0,05$, the level of development of digital competence in the discipline "Mathematical Analysis" among students of technical faculties of the experimental group studying the discipline using an electronic notebook is higher than among students of the control group studying the discipline without using an electronic notebook.

\section{Discussion}

The authors paid special attention to the issues of student involvement in the educational process and the effectiveness of organizing interaction with the teacher. The independent work of students was analyzed. To assess these indicators, the reflexivity questionnaire of Karandashev (Table 2). The questionnaire consists of 33 questions. Testing time is 15 minutes. The reflexivity indicator is defined as the sum of the numerical indices of the respondents' answers according to the key. Up to 49 points characterize low reflexivity, from 50 to 59 points - average reflexivity, from 60 and above - high reflexivity.

Table 2. Results of the level of development of reflection before and after the experiment.

\begin{tabular}{|c|c|c|c|c|c|c|}
\hline \multirow{3}{*}{ Group } & \multicolumn{6}{|c|}{ Level of reflexivity, \% } \\
\hline & \multicolumn{2}{|c|}{ Low } & \multicolumn{2}{|c|}{ Medium } & \multicolumn{2}{|c|}{ High } \\
\hline & before & after & before & after & before & after \\
\hline $\mathrm{RG}$ & 85.6 & 62.3 & 14.4 & 36.4 & - & - \\
\hline TG & 82.7 & 41.5 & 15.3 & 50.5 & - & 8 \\
\hline
\end{tabular}

Analysis of statistical data shows that there is an increase in the level of reflection in both the experimental and control groups. Thus, the level of reflection increases at all stages of training, but in the experimental group, it approaches a high value, which allows us to assert the success of the experimental work.

To diagnose the level of digital competence, in addition to analyzing the examination score, the authors tried to choose a methodology for assessing not only the cognitive component, but also the activity component. The work used a test developed by Microsoft, some of the questions of which were updated in accordance with modern requirements, based on the criteria of the All-Russian study "Index of digital literacy of citizens of the Russian Federation-2017" - a project of the Regional Public Organization "Center for Internet Technologies" (ROCIT), directed to measure the level of knowledge and skills of the population necessary for the safe and effective use of digital technologies and Internet resources [19] (Table 3).

Table 3. Analysis of the level of digital competence according to the criteria of the All-Russian study "Index of digital literacy of citizens of the Russian Federation-2017".

\begin{tabular}{|c|c|c|c|c|c|c|c|c|c|c|}
\hline Group & \multicolumn{9}{|c|}{ Digital Competence Level, \% } \\
\cline { 2 - 11 } & The digital age & \multicolumn{1}{|c|}{$\begin{array}{c}\text { Internet, cloud } \\
\text { services }\end{array}$} & \multicolumn{2}{c|}{$\begin{array}{c}\text { Standard } \\
\text { programs }\end{array}$} & \multicolumn{2}{c|}{$\begin{array}{c}\text { Privacy and } \\
\text { security }\end{array}$} & \multicolumn{2}{|c|}{$\begin{array}{c}\text { Basic } \\
\text { information }\end{array}$} \\
\cline { 2 - 11 } & before & after & before & after & before & after & before & after & before & after \\
\hline RG & 54.4 & 53.3 & 38.7 & 39.5 & 46.5 & 50.1 & 35.3 & 38.1 & 50.2 & 49.3 \\
\hline TG & 45 & 64.6 & 34.2 & 70.3 & 45.6 & 77.2 & 38.6 & 45.1 & 52.3 & 80.8 \\
\hline
\end{tabular}

Thus, the pilot study and the analysis conducted (Table 4) make it possible to conclude that the use of an electronic course and its component - an electronic notebook, contributes to an increase in the level of development of digital competence of students of technical faculties, since there is a positive dynamics in the development of the studied competence. 


\section{Conclusion}

Issues related to assessing the level of development of digital competence of students in technical areas, formed when working with e-courses, have been insufficiently studied, since the technology of introducing e-learning in the educational process is currently not widespread enough.

A further prospect of researching the problem will be aimed at solving issues related to the intensification of existing methods and technologies that are relevant for the development of digital competence of students.

\section{References}

1. X. Shen et al., Automatic recommendation technology for learning resources with convolutional neural network, in International Symposium on Educational Technology, 30-34 (ISET, 2016). https://doi.org/10.1109/ISET.2016.12

2. I.I. Lysova, O.A.Vitokhina, O.V. Volkova, Iss Journal, Edu, Linguist, 39(3), 408-418 (2020)

3. A.S. Imran, et al., An Analysis of Social Collaboration and Networking Tools, in P. Zaphiris, A. Ioannou (eds), Learning and Collaboration Technologies. LCT 2016. Lecture Notes in Computer Science, 9753 (2016). https://doi.org/10.1007/978-3-319-39483-1_31

4. I. Maslova, G. Burdina, I. Krapotkina, Int J Emerg Tech Learn, 15(16), 68-79 (2020)

5. V.A. Shershneva, et al., Europ J Contemp Edu, 17, 357-367 (2016). https://doi.org/10.13187/ ejced.2016.17.5357

6. G.U. Soldatova, E.I. Rasskazova, Nation Psych J, 2(14), 27-35 (2014)

7. N.P. Yachina, G.G. Fernandez, Bul VSU, Ser: Prob Higher Edu, 1, 134-138 (2018)

8. O.V. Prikhodko, Azimuth Sci Res: Pedag Psych, 9(1(30)), 235-238 (2020)

9. S.M. Kosenok, T.N. Kurenkova, Human Sci Bul, 11, 25-31 (2020)

10. E.A. Barakhsanova et al., IEJME-Math Edu, 11(10), 3447-3456 (2016)

11. V.A. Gaeva, D.Yu. Zakharov, Open Edu, 1, 65-69 (2014)

12. J.K. Tarus, Artif Intell Rev 50, 21-48 (2018). https://doi.org/10.1007/s10462-017-9539-5

13. C.Y. Yang, et al., Learning performance evaluation in e-learning with the webbased assessment, in K. Kim, N. Joukov (eds), Information Science and Applications 2017. ICISA 2017. Lecture Notes in Electrical Engineering, 424 (2017). https://doi.org/10.1007/978-981-10-4154-9_74

14. Ob Utverzhdenii Federalnogo Gosudarstvennogo Obrazovatelnogo Standarta Vysshego Obrazovaniya - Spetsialitet po Spetsialnosti 11.05.01 Radioelektronnye Sistemy i Kompleksy [On the approval of the federal state educational standard of higher education - specialty in the specialty 11.05.01 Radio electronic systems and complexes]. Accessed on: October 14, 2021. [Online]. Available: http://www.fgosvo.ru/news/21/3570

15. I.I. Ilyina, L.N. Vasilyeva, Napravleniya ispolzovaniya sovremennykh IKT pri podgotovke bakalavrov tekhnicheskikh napravlenii [Directions of the use of modern 
ICTs in the preparation of bachelors of technical directions], in A.N. Matveeva (ed), Actual problems of methods of teaching mathematics. Collection of reports and scientific articles based on the materials of the regional scientific and practical conference, 98-101 (2019)

16. G.J. Hwang, H. Xie, Knowl Manag E-Learn: Int J, 10(4), 371-374 (2018). https://doi.org/10.34105/j.kmel.2018.10.022

17. L.N. Vasilyeva, et al., Sci Edu Today, 10(2), 124-137 (2020)

18. N.I. Svetlova, N.A. Efimova, Elektronnaya rabochaya tetrad kak dopolnitelnoe sredstvo formirovaniya tsifrovoi kompetentnosti subektov obrazovatelnogo protsessa [Electronic workbook as an additional means of forming digital competence of subjects of the educational process, in Socio-humanitarian and legal problems of modern society: digital reality], 10-19, Materials of the XX interuniversity scientific conference on general humanitarian, legal and economic issues. Cheboksary, MGEU CHI (f) February 27, 2020 (LLC "Publishing House "Pegas", Cheboksary, 2020)

19. Vserossiiskoe issledovanie. Indeks tsifrovoi gramotnosti 2017 [All-Russian research. Index of digital literacy 2017]. Accessed on: October 14, 2021. [Online]. Available: https://rocit.ru/uploads/769c4df4bc6f0bd6ab0fbe57a056e769b8be6bcf.pdf 